\title{
THE IMPACT OF COVID-19 ON LEARNING SYSTEM TOWARD QUALITY EDUCATION: THE FUTURE OF GLOBAL EDUCATION OUTLOOK
}

\author{
James Kalimanzila $^{1)}$, Lwitiko Gladson Mwaikuju ${ }^{2)}$, Girindra Putri Ardana Reswari ${ }^{3)}$ \\ ${ }^{1)}$ Universitas Airlangga, Indonesia \\ E-mail: kalimanzilajames@yahoo.com \\ ${ }^{2)}$ Nduguti Secondary School, United Republic of Tanzania \\ E-mail: lwitikogladson@gmail.com \\ ${ }^{3)}$ Diponegoro University, Indonesia \\ E-mail: girindra.reswari@live.undip.ac.id
}

\begin{abstract}
The purpose of this study is to analysis the impact and challenges of covid-19 on learning system towards quality education. Currently, the World is facing pandemic COVID-19 which was experienced and appeared first in Wuhan-China around the end of 2019, it spread rapidly in the World. The COVID-19 pandemic has extraordinary impacts on education, economy, and other many sectors. However, the impacts will not only face and disturb only education sector, it will face other sectors including the future of work, healthcare, culture, economic, human relation among others. This paper collected data using qualitative method based on secondary information collected from various sources such as use of social media as document analysis methods, published and unpublished articles, newspapers, books, and reports of various education organizations, Universities sites and student forums. In this paper, the authors have analyzed the impact of the COVID- 19 on learning system.
\end{abstract}

Keywords: Learning System; Covid-19; Education; Challenges; E-learning

\section{INTRODUCTION}

The world is now facing the greatest threat since the Second World War which is the disease caused by the virus known as COVID-19. The disease started from Wuhan the capital city of Hubei province in the People's Republic of China then spread to the World rapidly. A report from World Health Organization indicates that by 31st December 2019 had some information about cases of pneumonia unknown cause detected in the city of Wuhan (WHO, 2020). It was later discovered that there was the presence of new type of the corona virus which according to the (WHO, 2020) the new ty of corona virus was isolated on 7 January 2020.

Furthermore, this study will demonstrate the multiple sides of COVID-19. The impact of COVID-19 is expected to point out and view a shadow in both negative and positive ways across the years and decades ahead. It will impact how human work, their lives, and what different businesses will look like in the future. Yet, the people and government need to have a creative thinking framework to consider the potential long-term impacts of the COVID-19 pandemic and to learn their learning system during this hard time. Likewise, most of student they are using online system, however there some countries don't have this system, or the coverage is not stable to facilitate all students.

According to Hannahan (2020) education system worldwide has been affected and forced more than 1.5 billion students out of school and universities. Having example in Tanzania the spread of COVID-19 forced the government to close all the schools and university indefinitely from 17th of March 2010 to prevent the spread of the virus. The effects of the disease save as an important reflection point for education systems worldwide to question and gauge the existing state of education and explore new opportunities to delivering quality education to billions of children worldwide. What measures should be taken by the global education community and how the situation is going to shape the future education system and the global outlook.

Moreover, relevant reports and findings about the global phenomena of education condition during pandemic. As an overview, UNESCO (2020) reported that some new policies such as social distancing and stay home then forced the learning system to be moved to learn from home as an impact of shut down the schools in all level of education in 
more than 40 countries in four continents. However, this cause a serious concern on some schools that do not have online learning platform. On the bright side, according to THE (2020) and Hodges et al (2020), this phenomenon then suddenly moves the educational institution to online education and distance learning.

Talking specifically about new way of learning system, even if almost all educational institution in all over the world already implemented, the dynamic debates upon this issue keeps continuing. Some issues raising up are related to the readiness, the practical implementation, the effectivity, and the quality of education. It is therefore, this paper will try to discuss and analyze deeper the changes, challenges, opportunities, and future education of education in COVID19 as a part of the contribution worldwide debates.

This study adopted the Edward N. Lorenz's (1961) butterfly theory. The theory imposes the phrase that starts that single flap of a butterfly's wings in Brazil generates a minor atmospheric disturbance continuously expanding to produce a tornado in Texas a month later. This theory holds the assumptions that small events may generate large consequences. According to Strother (2018) the theory was used first in meteorology and recently it has been applied to other fields like Economics. Strother (2018) uses the butterfly theory in their study Crises management, in their study they suggest that "leaders in their organization should prepare contingency plans for small and low probability events that might result in a crisis. Many of these events can be anticipated including natural disasters, severe weather, fires, chemical spills, bus crashes, bomb threats, disease outbreaks, terrorism, active shooters, and employee malfeasance." To this theory any crises has its own effects, it's up to the people involved to project the magnitude of the impact and prepare on how to deal with the impact of the crises. This theory was suitable for this study because it allowed the researchers to understand the covid-19 crisis and be able to explain the challenges of the eruption of COVID19, opportunities and future global-outlook in relation to learning system and quality education.

\section{The Current Trends in Education System}

Despite the fact that COVID-19 is affecting every sphere of human life, the immediately impact can be seen in education system causing the total closure of schools and universities impacting students worldwide. According World Bank (2020) reports around March 25 over one billion students all over the world were affected by the school closure due to COVID-19. School closure came as an implementation of the recommended measure of social distancing to slow down the spread of the COVID-19.

These taken measures of preventing the spread of COVID-19 left a puzzle to both students and teachers while to the government it is a call for abrupt changes on the way the education system used to operate in order to accommodate the current situation. The immediately measures were needed because closing school without any plan to make sure learning continues to take place could jeopardize the realization of the Quality education among students from different learning system worldwide, hence the need to make sure the changes has to reflect and shape the education system towards the realization of the quality education.

In another hand, The task of government and education institution to ensure the quality is according to Madani (2019) and Zedja (2018) the definition of quality of education is that the education itself should always be flexible for change to cope with educational evolution and its continuous progress even if it is influenced by various changing factors; such as, politics, culture, and economy. EFA Global Monitoring Report (2005) explained two principles of education quality. Those are: to recognize the cognitive development of learner's as the major objective of all education systems; to highlight the role of education in promoting the values and attitudes of the learners and in nurturing their creative and emotional development.

On the other hand, the students are stressed and frustrated especially those who were in their last year of their studies asking themselves when are they going to finish and what is going to happen to them. However, this can be a source of death and committing suicide because of these stress from Covid-19 and studies plans. The experience shows that stress and frustration kill easily compared to diseases.

International Institute for Higher Education in Latin America and the Caribbean (IESALC) (2020) asserts that to the student's undergraduates and those who are about to finish upper secondary and aspire to enter higher education are left puzzled wondering when is the situation going to end. The stress from the students came from the fact that the school closure is indefinite as nobody knows when the cure or the vaccine for the COVID-19 is going to be found. Hamouce (2020) stated that during this COVID-19 several severe issues impacted a lot to the society such as psychological distress and depression including perception of safety, risk and threat of contagion, quarantine, stigma and social exclusion, and the worst scenario which are financial loss and job insecurity (Hamouche, 2020).

This left students in a puzzle situation and the immediately effects to students can be seen particular in terms of economically where by the loss and cost the students incurred it's seen as a loss. Moreover, World Bank (2020) in their report suggested that extended interrupted education that disengage students from the learning process has the potential cost of reversing gains in learning results. This happen because the students lacks time and space to engage and involved effectively in the learning process.

Following the lockdown and the shutdown of the schools many countries started to look for alternatives to make sure each student gets equal chances of getting education. The literature on the current trends of education system and quality education are vast (Hillman 2020, UNESCO 2020, World Bank 2020, IESALC 2020, Hannahan 2020). World Bank (2020) asserts that "while schools are closed, many countries have turned to distance learning as a means of mitigating for lost time in continuing education services." This implies schools had to come up with different measure to make sure learning process takes place as usual. Many 
countries turn to the online classes where by face to face interaction between teachers, materials and students is replaced by online teachers and other webinar discussion. IESALC (2020) asserts that during the process many teachers lost their jobs both permanent and temporary teachers.

\section{Changes Brought by Covid-19 Crisis}

The COVID-19 spread came with a lot of changes in every sphere of life economically, politically, and socially. Due to a massive number of people being infected by the virus and forced to stay home and some died from the sickness in return the world witnessed a gigantic tumbling in production in the economic sectors worldwide. An article from International Labour Organization (ILO) issued on $18^{\text {th }}$ march 2020 on covid-19 and the world of work: impact and policy responses noted that "disruption of production, initially in Asia have now spread to supply chain across the world" this implies that due to disruption of production many businesses are facing a serious threat of closure of their business while consumers are facing the threat of scarcity of goods and services due to the eruption of COVID-19. International Monetary Fund (IMF) in 2020 mentioned some business sectors that get the most major effects of COVID-19. Those are business in relation to consumer shopping behavior, global advertising, and essential industries like food, medical, travel, and transportation.

Besides of those sectors, Ozili (2020) in his study asserts that many private sectors banks had the highest exposure to credit risk during the outbreak of COVID-19, this is due to the to the rise of the nonperforming loans issued to small and medium scale enterprises. This implies that many private sectors banks and other enterprises are in danger of demise and some facing a total closure under these circumstances. This is a threat to economy in many countries as it could lead to the occurrence of economic depression worldwide.

On the other hand, in education system both teaching and non-teaching staffs lost their jobs because of school closure in both private. The report from IESALC (2020) due to closure of school many schools and higher education temporary contracts may be terminated. This implies that many people are left jobless due to the closure of schools as a results of eruption of COVID-19. Viner, Russell, at all (2020) in their article noted that "the economic harms of school closures are high. A UK study14 from 2008 suggested that approximately $16 \%$ of the workforce are the main caregivers for dependent children and are at very high risk of absenteeism if schools are closed, a proportion that rises to $30 \%$ in the health and social care sectors." This literary implies that over $16 \%$ people who used to work as caretaker a portion that rises to $30 \%$ in the health and social care are left jobless. However, on the other hand, the closure of school helped in the slowed down and blocking the spread of the COVID-19.

Moreover, COVID-19 brought new experience worldwide from social distancing, lockdown, personal hygiene to mask wearing. Instantaneously after the outbreak of COVID-19 WHO gave guidelines on how to prevent the spread of
COVID-19, the earliest measures given which highlighted the improvement of personal hygiene which includes washing hands frequently with soap using water that's flows, using sanitizers, avoid touching your face and other peoples and maintaining social distancing (lmeter space from one person to another).

In the article updated on 29th April 2020 WHO provided the following guidelines for people to reduce their chances of being infected or spreading COVID-19 by taking some simple precautions:-

Regularly and thoroughly clean your hands with an alcohol-based hand rub or wash them with soap and water. Why? Washing your hands with soap and water or using alcohol-based hand rub kills viruses that may be on your hands.

Maintain at least 1 metre (3 feet) distance between yourself and others. This is because when someone coughs, sneezes, or speaks they spray small liquid droplets from their nose or mouth which may contain virus. If you are too close, you can breathe in the droplets, including the COVID-19 virus if the person has the disease.

Avoid going to crowded places. Why? Where people come together in crowds, you are more likely to come into close contact with someone that has COIVD-19 and it is more difficult to maintain physical distance of 1 metre (3 feet).

Stay home and self-isolate even with minor symptoms such as cough, headache, mild fever, until you recover. Have someone bring you supplies. If you need to leave your house, wear a mask to avoid infecting others. Why? Avoiding contact with others will protect them from possible COVID19 and other viruses.

These measures in its totality changed human whole circle of day to day life, before the eruption of the COVID-19 virus people didn't care about wearing masks or keeping social distancing but now it has become normal to everyone. Moreover, countries like Tanzania, Uganda, and Zimbabwe among others made it like regulation for people to wear mask and put buckets of water and soap for people to wash their hands.

Apart from the above measures suggested by WHO many countries decided to adopt lockdown, lockdown was done was of two types whereby some countries like Uganda, Rwanda among others adopted a total lockdown whereby borders were are closed to avoid people from external to enter the country and curfew is to be observed, while others practices partial lockdown example Kenya whereby they started slowly by closing borders then they locked down cities like Nairobi and Mombasa which were highly effected.

Generally this chapter reviewed different literatures on the COVID-19 and the current situation, economically, socially and politically worldwide. The literature about the life changes brought by the spread of the COVID-19 virus and the measures to taken to slowdown and prevent the spread of the viruses worldwide were reviewed in this section. 


\section{Methodology}

This study sought of adopting the qualitative research paradigm collecting data using different qualitative methods like collecting data from social media, publications, articles, book, and news broadcasting. This method named document analysis. Document analysis is a systematic procedure to review or evaluate document that can be taken from both printed and electronic materials (Byrne, 2001; Bowen, 2009). Similar with some other methods of research, document analysis can stand alone as a single research method. However, exactly similar with other methods of research, it is important to remember that document analysis also requires repeated review, examination, and interpretation of the data in to get the exact meaning and empirical knowledge of the construct study (Frey, 2018).

Specifically to the use of social media as document analysis methods, Lai \& To (2015) found that social media already become the most essential part that cannot be separated with human life because it succeed to affects all elements of human life such as the beliefs, values, and attitudes of people, as well as their intentions and behaviors.

Another method that is used in this research is interview method. Mack et al (2005) observe that an interview is a technique designed to elicit a vivid picture of the participant's perspective on the research topic. The information collected by this instrument helped the researcher enhance responses from other methods like Media publications, news broadcast, and made it possible for the researcher to cross- examine some key issues in the research. Informants had the opportunities to expand their ideas, explain their views and identify practices done in education system during the current situation of the COVID-19 towards realization of quality education, the challenges, the opportunities and the future global-outlook. The teachers spoke about the issues rises due to the closure of schools due to the outbreak of the covid-19, alternatives uses for the teaching and learning to still take place. The students talked about the changes and challenges during this period of time, opportunities for learning and the future global outlook. The study held the assumption that, the views the respondents gave were a reflection of their experiences with the learning system during the outbreak of the COVID-19 towards realization of quality education.

By and large this chapter discusses the methods used in this study for collecting data. The methods helped the researcher to collect as many data as possible which in turn helped the researcher to analyses the current situation in the education system practices and outcomes during the outbreak of COVID-19 towards the realization of quality education which are discussed and presented in the in the next chapter.

\section{RESULTS}

\section{Measures taken in fighting with Covid-19.}

It was observed that after the outbreak of COVID-19 many countries took different measures in order to reduce the spread of the virus. Many country decided to close schools and universities.as the precaution toward the spread of COVID-19, for example In Tanzania the Prime minister announced in March 16 that the schools are to be closed for 30 days immediately effectively from 17 th March to 17 th April, and he added that "this is to prevent the spread of COVID-19 in the country. On 18th March the prime minister announces again that all universities in the country should be closed for 30 days as the prevention measures following the outbreak of COVID-19 in the world. On 31st of March President Yoweli Museveni of Uganda ordered the closure of all schools in Uganda for 30days. Prior to these countries elsewhere in the world schools were closed to prevent the spread of COVID-19.

On the other hand, this meant that other techniques and methods of teaching has to come in to replace the classroom interaction to make sure learning is taking place as usual. Many countries turned to online teaching and learning as a solution. However, many the online teaching proved failure to many of the countries. Many articles cited low connectivity hinders the online teaching and learning in taking place in many countries. The choice for continuity solutions that demand connectivity is spreading globally when the reality is one of low connectivity in households in low- and middle-income countries. Generally there is very low numbers of students who can access the internet in Africa and Latin America (IESALC, 2020).

In East Africa only few schools and universities opted to use online learning as an option to learning process. One Student from GEMs international school in Uganda asserts that "in our school the studies continues as usual, we learn through online learning. Teachers send question even we do exams online too." Another student from public school in Uganda claimed that "since we closed school we have never learned anything, we are just waiting for it to open so that we can resume with our studies" This implies that in the same country students get different way of accessing education.

Moreover, elsewhere in Tanzania, Tanzania broadcasting corporation (TBC) is broadcasting lessons every week days for secondary school, students are supposed to seat and watch the broadcasts through TV. Moreover, some student claims that they receive questions and notes of different subjects from their teachers through whatsApp, telegram and other social media. One student's in particular studying form six asserts that "our teachers asked us to create whatsapp group using our parents' phones so that they can send us notes and questions for revision purposes" on the other hand, another students claimed that "I just learn on my own, I don't have a computer, I don't have a phone so it just me by myself. Even at school they did not give us the strategies on how we are going to study during this this time when 
schools are closed" This implies that although schools are closed many students do not have any accesses to learning.

Similar with what happened in Africa, the education system in South East Asia also then forced to be adjusted to be online. Several schools even most all of it been closed as a part of an effort to limit the further transmission of the pathogen. Even if the number of internet penetration across South East Asia based on the survey and report by Data report done by Kemp \& Moey (2019) was reached 63\%, South East Asia that mostly dominated with developing regions has a large segment of the population that do not have access to the Internet and electronic devices. It can be stated that there is a gap among the societies in each country in South East Asia in accessing the internet. According to ASEAN Statistical Report on Millennium Development Goals 2017, there are only three countries that has reached $80 \%$ active internet users from total population. Those are Singapore, Brunei, and Malaysia. Other countries such as Indonesia, Thailand, Myanmar, and Vietnam only have less than $60 \%$ internet penetration.

Even if it is reported by the statistical report that the users are keep growing for example Indonesia which also becomes the South East Asia's largest population with $20 \%$ of growing in the past two years or equating to an increase of roughly 29 million new users, online distance learning presents a challenge. Even before COVID-19, Indonesia was struggling with the equality of education. Students living in a city might not have problems with internet or knowledge's dealing with internet. However, students living in urban area faced the problems. Even some of the areas are still facing weak internet connection.

As a background, Indonesia closed all schools in early March with total number of 60 million students should learn from home. The learning system then move into home-based learning using a number of free digital platforms facilitated by the government and private (UNESCO, 2020). With a very huge number of populations, Indonesia is predicted to suffer over longer time period compared to the lesspopulated country (Satrio, 2020). This uncertainty then impacted to the implementation of education in Indonesia. One of the serious impacts is the cancellation of national exam of all level of schools in Indonesia.

Another serious issue faced by Indonesian education during the pandemic is students from poor families are disproportionately affected by school closures. As their parents or caregivers less aware of education because of their minimum level of education background, they may put their students need of education aside of the priority. When the parents or caregivers are struggle to achieve the basic needs, they might have tendency to be less aware of what is distance learning and what should they do to support that learning environment (UNESCO, 2020; Satrio 2020).

As an effort to help all students to enjoy learning during pandemic, The Ministry of Education and Culture is actively working with UNICEF and other development partners to identify other alternative modalities, such as TV, radio and printed materials to provide an opportunity for those who cannot access the internet the same chance to learn effectively. These efforts will be paired with mechanisms to monitor distance learning in real-time and to encourage parental involvement in their child's learning process (UNICEF, 2020).

\section{Challenges that hindering the realization of quality education}

Although online teaching and learning seems like the alternative and escaping route for the education system towards the realization of quality education during this pandemic, there are many countries which remained naïve towards the application of online technology. This can be caused by different challenges countries faces as discussed below.

Poor government support in introducing technology in schools and universities. Much as the teachers wish to use technology in teaching and learning process, the support from the government seems to be very poor. Countries like Tanzania majority of public schools and universities are not using technology in learning and teaching. One teacher noted that "in our school we don't have even a single computer, it is a government school so we depend on the fund provided by the government to buy everything we use, and the government haven't provided us with the fund to facilitate technological installation in our school" this shows that many schools doesn't have technology to support online teaching and learning.

Poor internet network and connection in many developing countries particularly African countries. For example in a country like Tanzania few people can access internet connection, majority of the people live in places where there are poor or no connection at all. A teacher from rural Tanzania was interviewed and claimed that "it is very hard in our communities for one to access internet which makes the online classes even more difficult, it is only very few people who can access internet", another teacher noted that "some students live in a very remote areas which makes it even impossible for the students to access internet connection consequently online learning cannot take place". This implies that countries technological system it is far backward to allow online learning to take place.

Other teachers suggested that the government has not invest enough in the online learning, hence it is hard for the online learning to be used as an alternatives for teaching and learning because there are no tools enough to facilitate the process. On the other hand, when the researcher asked the teacher whether they have ever try online teaching many of them said they have never use it neither in teaching nor in learning. One teacher particularly noted that "in our school there are no computers or internet connection, this makes it even hard to think about it" in return this makes online teaching and learning even more impossible.

Technological illiterate among teachers and students in many countries worldwide. Many people in general do not have enough knowledge on technology this makes it even harder to put it into application in teaching and learning. One teacher from Tanzania when asked whether they have knowledge and skills on application of technology claimed 
that "I personally cannot operate a computer let alone use it in teaching and learning. I have never try technology application in teaching and learning" In return this limit students from accessing education during time like this where schools are closed and there is no alternatives to learning. On the other hand, some students when asked if they know anything about online learning the claimed that they don't know what that is. When the student were asked if they know how to operate a computer or a cellphone, some claimed that they have never used a computer and their schools does not allow cellphones so they don't own. One student specifically said "I have never touched a computer or use a cellphone which has access to internet" this shows how illiterate peoples are in technology.

This chapter presented the findings of the study Learning System and COVID-19 towards Quality Education; Changes, Challenges, Opportunities and the Future Global Outlook. The findings presented are obtained through interviews, and other sources of data media, publications, and news broadcasting.

\section{Discussion}

This chapter discusses of the findings in chapter four and draws conclusion and make recommendations basing on the study findings among and literature review. The discussion will be presented in the following themes;

1. The situation in education system.

2. The effect of the current situation to quality education.

3. The opportunities for the future improvement (recommendation)

\section{The current situation in education system.}

The situation of education system in many countries is still the same. Many countries especial in Africa, teaching and learning process is still done in analogy way where teachers and students meet manually and interact face to face. Observations shows that many education system Africa public schools and universities in particular where majority of student goes don't use technology in teaching and learning. In an interview one teacher claimed that "I personally cannot operate a computer let alone use it in teaching and learning. I have never try technology application in teaching and learning" this shows that many teachers in Africa use the face to face interaction in teaching and learning process. This type of interactions has been here for long which means in many countries education system has not evolve much to application of technology.

This has been caused by lack of funds to facilitate the install technological tools in schools. Many schools just get funds to facilitate analogy tools like books, chalks and chalkboards, of teaching and learning and not tools like computers, televisions and radios to facilitate digital and online learning and teaching. During an interview one teacher noted that "in our school we don't have even a single computer, it is a government school so we depend on the fund provided by the government to buy everything we use, and the government haven't provided us with the fund to facilitate technological installation in our school." This is the reason why the schools fails to continue with the teaching and learning during the lockdown and school closure.

\section{The effect of the current situation to quality education.}

The findings of the study shows that majority of the students in many country didn't get the chance to continue with learning. The situation was caused by the lack of technology to allow online learning. During an interview on student claimed that "I just learn on my own using my books and notes, I don't have a computer, I don't have a phone so it just me by myself. Even at school they did not give us the strategies on how we are going to study during this this time when schools are closed". This affects and set boundaries to students' access to quality education since the student is limited to the same books and notes he has been using he can't access other alternatives to learning, this limits his abilities to meet and discover his potential. This goes against what UNESCO has been for so long insisting that the education provided has to generate skills and abilities that matches and reflect the demand of the modern world.

The learning outcomes of a students who passed through this tough times of epidemic and school closure is not going to reflect quality education. This effect is what the theory of the butterfly effect illustrate about, the COVID-19 as a crisis effected the education system which in return affected the education system and the outcome of the students' learning. School closure and the situation of the students fail to continue learning came as the effect of the COVID-19.

Besides all those challenges, some of the organization tried to help the education globally to ensure its quality under the different learning style. INTERNATIONAL ASSOCIATION OF UNIVERSITIES (IAU) in April 2020 created a document consists of the compilation of information of COVID-19 on higher education around the world by collecting some sharing information from the world. Inside of this document, we could find many helpful resources such as links of possible solutions or initiatives from UNESCO, University Association from all over the world for example Association of American Colleges and Universities (AACU), Association of Indian Universities, Council for Higher Education Accreditation (CHEA), and many more. Also, some universities all over the world, World Bank, World Digital Library, and many other education institutions. It is also provided the news from all over the world by region and by country.

UNESCO in their website also created list of educational applications, platforms, and resources for all parents, teachers, schools, and school administration to facilitate students learning. It is entitled 'Distance Learning Solution' which most of them are free, and many carter to multiple language. The example of the list is 'Digital Learning Management System' which has CenturyTech - Personal learning pathways with micro-lessons to address gaps in knowledge, challenge students and promote long-term memory retention, Google Classroom - Helps classes connect remotely, communicate and stay-organized. 


\section{The opportunities for the future improvement (recommendation)}

In order for any education system to meet quality education in all levels of education, there must be things that are to be done by both the government, schools and students and teachers and education stake holders. These things are explained below:-

The government should fund schools to install technological instruments that can facilitate digital learning. Things like computers, projectors, recording systems, radios, television among others need to be installed in schools and universities to facilitate online teaching and learning. This will give all the students access to the learning contents which is one stake of quality education.

Teachers should be trained to use technological gadgets in teaching and learning process in order to be able to use them in their teaching and learning. This is because many teachers when interviewed claimed they don't know how to use the gadgets specifically computers and projectors in their teaching process. This will facilitate teachers in making sure quality education.

There should be radio and television channels specifically designed for the purpose of airing the education content and should be designed to cater all levels of education. This will be very helpful in times like this where schools are closed because of COVID-19, students can be able to seat and watch or listen to the aired subject. This will make the student busy and time will not be wasted at all. And these content should be provided for free and they should be accessible anytime.

Not only eruption of COVID-19 speckled and exposed the strength and weakness of many education system in terms of how they respond to the crises and the weakness toward the realization of quality education, but also it gives a room to these education systems to improve.

\section{CONCLUSIONS}

All in all, Covid-19 has brought many impact in every aspect of human life, economically, politically, socially and psychologically. However, education sector have been affected mostly in every part of the World. Many schools and Universities have been closed for temporary and unknown time due to social distance and lockdown policy as one of the solution toward pandemic covid-19. Due to these changes the learning system have forced to change its style by adopting online studies and webinar. Moreover, some countries still have challenges on implementing this due to poor infrastructure and internet facilities. Furthermore, after covid-19 learning education system will keep changing and become more digitalized toward the era 5.0. Likewise, autonomous education will take its momentum.

\section{REFERENCES}

Bowen, G. A. (2009). Document analysis as a qualitative research method. Qualitative research journal, 9(2), 27.

Frey, B. B. (Ed.). (2018). The SAGE encyclopedia of educational research, measurement, and evaluation. Sage Publications.

Hannahan, P. (2020, April 27). Adapting approaches to deliver quality education in response to COVID-19. Retrieved May 23, 2020, from https://www.brookings.edu/blog/education-plusdevelopment/2020/04/23/adapting-approaches-todeliver-quality-education-in-response-to-covid-19/.

Hilman, N. (2020, April 2). Covid-19 could be a curse for graduates but a boon for ... Retrieved May 23, 2020,

from https://www.timeshighereducation.com/opinion/cov id-19-could-be-curse-graduates-boon-universities

Hodges, C., Moore, S., Lockee, B., Trust, T., \& Bond, A. (2020). The difference between emergency remote teaching and online learning. EDUCAUSE Review. Https://Er. Educause. Edu/Articles/2020/3/theDifference-between-Emergency-Remote-

Teachingand-Online-Learning.

IMF. (2020). CHAPTER 1 THE GREAT LOCKDOWN (Full Report to Follow in May 2020). World Economic Outlook, (April).

INTERNATIONAL ASSOCIATION OF UNIVERSITIES (IAU). "Covid-19: Higher Education Challenges and Responses." IAU, Apr. 2020, www.iauaiu.net/Covid-19-Higher-Education-challengesand-responses.

Kemp, S. (2019). Digital 2019: Indonesia. Retrieved from Datareportal: Com/reports/digital-2019-indonesia.

Lai, L. S., \& To, W. M. (2015). Content analysis of social media: A grounded theory approach. Journal of Electronic Commerce Research, 16(2), 138.

Madani, R. A. (2019). Analysis of Educational Quality, a Goal of Education for All Policy. Higher Education Studies, 9(1), 100-109.

Noe R. (2009), Learning system design; A guide to creating learning initiatives, SHRM Foundation. United States of America.

Noe, R. A. (2009). Learning system design: A guide to creating effective learning initiatives. SHRM Foundation.

Pia, T., Galynker, I., Schuck, A., Sinclair, C., Ying, G., \& Calati, R. (2020). Perfectionism and Prospective Near-Term Suicidal Thoughts and Behaviors: The Mediation of Fear of Humiliation and Suicide Crisis Syndrome. International journal of environmental research and public health, 17(4), 1424.

Satrio, A. (2020). Indonesia's Fight against COVID-19: A Battle over the Meaning of Emergency. Verfassungsblog: On Matters Constitutional. 
Secretariat, A. S. E. A. N. (2017). ASEAN Statistical Report on Millennium Development Goals 2017. Jakarta (ID) ASEAN Secretariat.

Strother, S. C. (2018). Butterfly Theory of Crisis Management. Global Encyclopedia of Public Administration, Public Policy, and Governance, 646-649. Doi: 10.1007/978-3-319-20928-9_883

Strother, S. C. (2018). Butterfly Theory of Crisis Management. Global Encyclopedia of Public Administration, Public Policy, and Governance, 646-649. Doi: 10.1007/978-3-319-20928-9_883

THE. (2020). what might Covid-19 mean for the World University Rankings? | Times Higher Education (THE). Retrieved May 16, 2020, from https://www.timeshighereducation.com/worlduniversity-rankings/what-might-covid-19-meanworld-university-rankings

UNESCO. (2005). EFA Global Monitoring Report 2005: Education for All - The ... Retrieved from https://www.right-to-education.org/resource/efaglobal-monitoring-report-2005-education-all$\%$ E2\%80\%93-quality-imperative

UNESCO. (2020). Distance learning solutions. Retrieved May 16, 2020, from https://en.unesco.org/covid19/educationresponse/so lutions

UNESCO. (2020). How to plan distance learning solutions during temporary ... Retrieved May 23, 2020, from https://en.unesco.org/news/covid-19-10-

recommendations-plan-distance-learning-solutions

UNESCO. (2020). UNESCO's support: Educational response to COVID-19. Retrieved May 23, 2020, from

https://en.unesco.org/covid19/educationresponse/su pport

Viner, R., Russell, S., Croker, H., Packer, J., Ward, J., Stansfield, C., Booy, R. (2020). School Closure and Management Practices during Coronavirus Outbreaks Including COVID-19: A Rapid Narrative Systematic Review. SSRN Electronic Journal. doi: $10.2139 /$ ssrn. 3556648

World Bank. (2020). Coronavirus disease (COVID-19) advice for the public. Retrieved May 23, 2020, from https://www.who.int/emergencies/diseases/novelcoronavirus-2019/advice-for-public

World Bank. (2020). How does COVID19 impact education? Retrieved May 23, 2020, from http://pubdocs.worldbank.org/en/450881585235950 757/COVID19-Education-Sector-Guidance-NoteMarch26.pdf
World health organization. (2020). COVID-19 situation reports - World Health Organization. Retrieved May 23, 2020, from https://www.who.int/emergencies/diseases/novelcoronavirus-2019/situation-reports

Zajda, J. (2018). Quality debate in education: Researching dominant paradigms. World Studies in Education, 19(1-2), 49-60. 